DOI: $10.17516 / 1997-1370-0669$

УДК 328.185

\title{
Corruption System against Russia
}

\author{
Vitaly A. Nomokonov* \\ Far Eastern Federal University \\ Vladivostok, Russian Federation
}

Received 06.08.2020, received in revised form 31.08.2020, accepted 25.09.2020

\begin{abstract}
Today the corruption has become a major threat for the national security. Not only individual corrupted officials and embezzlers turn against Russia, but also a huge and powerful corruption system. Analysis of the corruption as a negative social phenomenon shows that it implies the totality of all corruption acts, all corrupted officials, as well as an entire independent corruptogenic system. This system often lacks the attention of analysts. Corruption has now acquired a systemic character in Russia. The institutions involved in the study of the corruption phenomenon in Russia include the Law School of Far Eastern Federal University, where in June 1997 the Vladivostok Centre for the Study of Organized Crime was established as part of a wider initiative of American University's Transnational Crime and Corruption Center (TraCCC) to create and support United Research Centres on Organized Crime in Eurasia. The Centre researchers study the patterns and development of organized crime as well as methods of defeating the socially devastating manifestation of organized crime and the closely associated phenomena of corruption, money laundering, contract killings, illegal narcotics trade, etc. The Vladivostok Centre has produced a large body of research, analysis, translated international literature and popular scholarly works; it has prepared a number of books, textbooks, and academic articles, including many concerning corruption. The inefficiency of the state's efforts to combat corruption is explained by the fact that the main corruption-causing factors remain unaddressed. They include deformation of the political sphere (privatization of the state, the absence of a real separation of powers, the dominance of the executive branch of government over all others, lack of necessary rotation, irreplaceable officials, lack of transparency, the presence of "shadow" power and "shadow" law).
\end{abstract}

Keywords: corruption, causes of corruption, anti-corruption preventive measures, anticorruption enlightenment, anti-corruption competences.

Research area: law.

Citation: Nomokonov, V.A. (2020). Corruption system against Russia. J. Sib. Fed. Univ. Humanit. Soc. Sci., 13(10). 1638-1643. DOI: 10.17516/1997-1370-0669.

\footnotetext{
(C) Siberian Federal University. All rights reserved

* Corresponding author E-mail address: nomokonov@rambler.ru ORCID: 0000-0002-5154-0408
} 


\section{Introduction}

Among those institutions that did not shy away from the study of the corruption phenomenon in Russia was the Law School of Far Eastern Federal University, where in 1997 the Vladivostok Centre for the Study of Organized Crime was established and where it functions today ${ }^{1}$. The Center was founded within a wider initiative of American University's Transnational Crime and Corruption Center (TraCCC) to create and support United Research Centres on Organized Crime in Eurasia. The Centre researchers study the patterns and development of organized crime as well as methods of overcoming the socially devastating manifestation of organized crime and the closely associated phenomena of corruption, money laundering, contract killings, illegal narcotics trade, etc. The Vladivostok Centre has produced a large body of research, analysis, translated international literature and popular scholarly works; moreover, it has prepared a number of books, textbooks, and academic articles, including many concerning corruption.

Today we are all witnessing an unprecedented range of publications on anti-corruption topics and the revitalization of various corresponding public forums in Russia. Contemporary Russia is characterized by an unparalleled growth in publications and rejuvenated anti-corruption activities done by numerous actors of civil society. In my opinion, this tendency is not so much a fashionable trend but rather a reflection of an appropriate reaction to the corruption phenomenon in Russia and the growth of public expectation of reduced corruption. This is seemingly not so much a tribute to market conditions but a real indicator of the seriousness of the corruption situation in Russia and, accordingly, the growth of anticorruption expectations in society. We also see that a cardinal turning point in the fight against corruption has not occurred so far.

More than that, I personally think that despite a whole package of anti-corruption legal measures, the introduction of National Strategy and National Anti-Corruption Plans, spe-

\footnotetext{
1 Similar Centres have also been established over the years in Moscow, St. Petersburg, Ekaterinburg, Irkutsk, Saratov, in Ukraine and in Georgia.
}

cialized anti-corruption units in government and administration, regardless of the frequent high-profile arrests of the most senior corrupted officials, corruption continues its destructive work and increasingly weakens the state more and more. Not only individual corrupted officials and embezzlers come down on Russia but huge and powerful corruption system.

This is a result of that, first of all, major corruptogenic factors remain outside the influence of state and public institutions and these factors themselves have been neither fully realized, nor studied deep enough. Most works on anti-corruption topics suggest that all what is covered is well known but key reasons of this negative phenomenon are reduced to the greed of officials and the imperfection of laws. There is a question, why the greedy officials still continue to occupy the halls of power, why the legislation does not improve?

\section{Theoretical framework}

One should say that there is no adequate understanding of corruption, even despite the known per se legislative definition. It should be clarified that the Federal Law "On Combating Corruption" (2008) defines corruption not as a social phenomenon but as an individual corruption act. They need to be distinguished. But the definition of corruption acts comes down to listing its various forms. All of them consist, as applied to individuals, of unlawful use by a person of his/her official position possibilities contrary to the legitimate interests of society and the state in order to obtain property benefits or illegal provision of such benefits to this person by other persons.

It is noteworthy that such an interpretation is narrower than that given in the UN Convention against Corruption (2003): here the focus is on the goal of obtaining any unlawful, not just property, advantage. Therefore, I'd support the proposal to clarify the legislative definition of corruption as a separate act and a broader interpretation of the purpose of such an act.

As for corruption as a negative social phenomenon, it implies the totality of all corruption acts, all corrupted officials, as well as an entire independent corruptogenic system. This system often escapes the reasoning of analysts. 
The wide scope and deep penetration of corruption into all the tissues of the social organism requires paying attention to a system of corruptogenic relations that provoke corrupt behaviour directly.

One of the most accurate definitions of corruption was formulated by a famous Russian specialist Prof. B.V. Volzhenkin: corruption is a social phenomenon consisting in the decomposition of power, when officials and other persons, namely persons authorized to perform public functions, use their positions, status and authority for mercenary purposes, personal profiteering or for lobbying group goals (Volzenkin, 1998). I will take an advantage of this definition in the future. One would precise that in addition to the mercenary purpose, another personal interest in obtaining any illegal benefit is possible.

\section{Statement of the problem}

Official statistics does not produce the real number of corruption crimes due to their extremely high latency in our country. If you try to assess the corruption situation in the country as a whole, then the discussion should, in my opinion, revolve around reaching a critical level at which a real threat to the security of the state has already arisen. This is openly talked about by many experts, this is evidenced by special sociological studies conducted in Russia during recent years, also numerous mass media reports have appeared. No one questions the statement that corruption in Russia has currently acquired a systemic character.

The Primorsky Krai is not an exception. A number of vice-governors were prosecuted for corruption crimes, and not only vice-governors, but also mayors, heads of municipalities, a rector and vice-rectors of the Far East Federal University, a head of the investigation division and a head of the criminal division in the Police Department of the Primorsky Krai, a former speaker of the legislative unit, etc.

\section{Discussion}

The inefficiency of the state's anti-corruption efforts is presumably explained by the fact that essential corruptogenic factors remain intact. An effective anti-corruption strategy in Russia should be based on an adequate understanding of features of the causes of corruption. It allows one to more deeply and accurately determine the main directions of the strategy to combat it. Ignoring this circumstance may lead not to a real fight against corruption, but only to its imitation.

Corruption is seemingly rooted in deformations of the political sphere (primarily), deformations of state power, its hypertrophy or, vice versa, underperforming. These deformations are quite substantial and it is regrettable that for various reasons they are most often somehow understated.

1) Commercialization (privatization) of the state. In our country, as a result of the transfer of a significant share of state ownership to private hands, our state, though declaring a commitment to common interests, was transformed, in fact, into a state of protection of a narrow layer of new wealthy owners, it has become a business project of clans fighting for power and property at all levels: federal, regional, municipal.

It should be recognized that, as a result of political confrontation in the $1990 \mathrm{~s}$, the ideology of the bourgeois consumer society with its priority of personal material enrichment dominated as a criterion of life success. State ideology, abolished by the new Constitution, has not gone anywhere de facto but only became indeed bourgeois, although it was not officially declared as such. The coup d'etat of the 1990s and the looting of the country following it under the cover of privatization by fraudsters and corrupt officials brought to power the most consistent and decisive carriers of the new ideology.

The political scientist V. Inozemtsev (as well as another authors) describes a system in which formal instruments of government are completely subordinate to the tasks of increasing the wealth of the country's leader, people close to him, their friends and relatives, and also all those whose political loyalty is needed by the "big boss" to maintain their power and ensure their own security. Enrichment of the political elite is the highest goal of the system and getting benefit from one's position is 
its fundamental imperative (Inozemtsev, 2019; Damaskin, 2009; Rose-Ackerman, 2003).

2) Next significant corruption factor is the lack of real separation of powers proclaimed by the Constitution of the Russian Federation and the clear dominance of the executive branch of power over other branches. Without going into discussions about where to take the President himself with his administration, one should remark that if you put them at over all branches of government, which takes place in reality, then you get connivance of authorities in terms of checking for corruption.

3) The lack of necessary rotation, mainly in the highest echelons of power. The irremovability of the country's leaders for a long time is unacceptable by virtue of the obvious propensity of corruption, for "power corrupts everyone".

4) Destruction of democratic principles of governance and persistent trends of authoritarianism, which is a consequence of hypertrophy of one of the branches of government and the reason for the growth of corruption.

5) Lack of transparency, secrecy of power relations and decisions is not just a favorable condition or favorable background of corruption, but its independent cause.

6) The presence of "shadow" power and "shadow" law. It is expressed not only in the direct penetration into the power of criminals, but also in other forms. Alas, many processes in present-day Russia instead of being realized in a civilized, open form occur "under the carpet", in shadow structures and shadow ways. There is a lot of data testifying to the formation and activities of parallel shadow political power in Russia. Today, the huge growth of the shadow (criminal) component is often corollary to that formal institutions (offices of president, governors or mayors and so on participate in the informal process). In the latter case, these structures do not function at a representative or government levels, but only at informal and personal (it is main one); they are pursuing self-serving and narrow corporate goals.

The specificity of the Russian political environment is that the informal field has become almost pointedly stronger than formal relations (Nomokonov, Popova, Filippov, 2018), i.e. "shadow" law ("concepts") embraces informal regulation of public relations and is dovetailed with the hidden illegal behaviour of officials (Ilyukhin, 2011; Sulakhsin, 2018; Korhzakov, 2018).

7) Corruption of legislation. Despite the existence of an institute of anti-corruption expertise, a lot of conspicuosly corruptogenic norms can be found in the current legislation. For example, the minimum limits of punishment were removed from a number of the Criminal Code's articles, thereby vastly increasing the breadth of the discretionary powers of judges. Also, the judge received the right to change the category of gravity of the crime at his discretion, which had been previously unacceptable. Confiscation was excluded from the punishment system. It was introduced again in three years but, nevertheless, not as a measure of punishment, which causes bewilderment. The punishment of up to 8 years of imprisonment may be imposed by the court on probation, including cases of corruption (but this practice was not legalized).

8) Lack of control on the part of civil society, as well as the actual lack of civil society itself. Unfortunately, public chambers and public councils neither have the authority to control the activities of officials nor are actually perfunctory.

Unfortunately, the state counteraction to corruption still does not practically affect its main economic reason - the shadow economy. Neither the National Strategy nor the National Anti-Corruption Plans even mention this serious cause of the latter.

A weighty corruption factor is the strongest stratification of the population. It is a manifestation of social injustice and a powerful factor in the growth of social tension.

Turning to the spiritual sphere of public life, we find a kind of "corruption syndrome": everyone has become, as it were, a subject of trade in an effort to "sell out smth at a higher price". In the public mind of Russian citizens, we now observe two interconnected social opinions. One of them is corruption dependence when corruption is perceived as an integral attribute of the lifestyle in Russia. Such a perception and an appropriate lifestyle are often 
incorrectly called the "social norm". I consider that "mass" or "massive" is not a synonym to "normality". Otherwise, we would come to the paradoxical conclusion that in Russia the Law is fighting or trying to fight normal behaviour that does not harm the individual, society or the state.

The second attitude can be described as corruption readiness. This means a psychological orientation to solving various problems through bribery. Perception of corruption as a "social norm" (it is not tantamount to recognizing it as such, only in the wording "everybody does it"), in turn, forms a psychological readiness to give bribes and take them. Ultimately, behind these deformations of public consciousness, it seems, there is hidden and even deeper deformation of value and regulatory system of social, group and individual consciousness. It is based on the recognition of money, capital, property as main values; hereby it leads to the alienation of the individual from society and the state and vice versa.

\section{Conclusion}

The escalation of corruption and the aggravation of its qualitative characteristics are natural for those conditions of society when at the same time, in one and the same system, firstly, the measure of everything is exclusively money, material values; spiritual values are devalued, a person's value is determined by the size of his/her personal fortune, regardless of how they have receives it. Secondly, any means for the sake of enrichment are justified. Thirdly, the Law does not even provide a minimum standard of living (Dolgova, 2003).

In my opinion, the largest anti-corruption potential lies with society, which is based on three fundamental points. First, in such a society priority shall be given to spiritual values over material goods. Second, the fundamental principle of social life becomes the principle of social justice above all, or the suitability of actions and reward for actions, the degree of service and reward for service, the degree of guilt and punishment. Third, in such a society social liberty presents the opportunity for the harmonious and multifaceted development of the individual, society and the state within clearly-defined and transparent boundaries.

On the other hand, the predominant materialism in society, the violation of the principle of social justice, the impaired liberty of some sectors of social life and the lack of transparency of social connections and actions inevitably give rise to corrupt activities.

Therefore, an additional cornerstone in the fight against corruption should be the strengthening of the state and its democratic collaboration with citizens, the division of state and personal interests, and the every possible reinforcement of the principle of social justice in society.

\section{References}

Damaskin, O. (2009). Korruptsia [Corruption]. Moscow, pp. 27-29.

Dolgova, A.I. (2003). Prestupnost', ee organizovannost' i kriminal'noe obshestvo [Crime, Organized Crime and Criminal Society]. Moscow, p. 533-546.

Ilyukhin, V. (2011). Voina za Rossiu [War for Russia]. Moscow, 240 p.

Inozemsev, V. (2019). Pochemu mi vse ziviom v kommercheskom gosudarstve Putina? [Why do we all live in the commercial state of Putin?]. In Snob. Available at: https://snob.ru/entry/179441/?utm_referrer $=$ https $\% 3 \mathrm{~A} \% 2 \mathrm{~F} \% 2 \mathrm{Fzen} . y$ andex.com.

Korhzakov, A. (2018). Besy 2.0. A tsari to nenastoiaschie! [Demons 2.0. And the kings are not real!]. Moscow, 210 p.

Nomokonov, V.A., Popova Y.Y., Filippov V.V. (2018). Tenevoe gosudarstvo kak kriminogennyi factor [Shadow state as a criminogenic factor]. In Kriminologia vchera, segodnia, zavtra [Criminology of yesterday, today, tomorrow], 1 (48), 57-61.

Rose-Ackerman, S. (2003). Korruptsia i gosudarstvo [Corruption and State]. Moscow, 343 p.

Sulakhsin, S.S. (2018). Rossiiskoe gosudarstvo prevrashaetsia v kriminalnoe [Russian state is turning into a criminal one]. In Rossiia v epokhu razvitogo putinizma. Materiali nauchnoi konferentsii [Russia in 
the era of the developed Putin regime. Materials of the scientific conference]. Moscow: Science and policy, pp. 10-18.

Volzenkin, V. (1998). Korruptsia [Corruption]. Saint-Peterburg, p. 6.

\title{
Коррупционная система против России
}

\author{
B.А. Номоконов \\ Дальневосточный федеральныгй университет \\ Российская Федерация, Владивосток
}

\begin{abstract}
Аннотация. Коррупция сегодня превратилась в главную угрозу национальной безопасности. Против России действуют уже не отдельные коррупционеры и казнокрады, а огромная и мощнейшая коррупционная система. Что касается коррупции как негативного социального явления, то в него входят: совокупность всех коррупционных деяний, все коррупционеры, а также целая самостоятельная коррупциогенная система. Вот эта система часто ускользает из поля зрения аналитиков. Коррупция в России в настоящее время приобрела системный характер. Неэффективность усилий государства по противодействию коррупции объясняется тем, что остаются нетронутыми основные коррупциогенные факторы. В их числе деформации политической сферы (приватизация государства, отсутствие реального разделения властей, доминирование исполнительной ветви власти над всеми другими, отсутствие необходимой ротации, несменяемость, отсутствие прозрачности, наличие «теневой» власти и «теневого» права), а также наличие теневой экономики, чудовищное социальное расслоение, идеология всеобщей продажности.
\end{abstract}

Ключевые слова: коррупция, причины коррупции, антикоррупционные превентивные меры, антикоррупционное просвещение, антикоррупционные компетенции.

Научная специальность: 12.00.00 - юридические науки. 